\title{
Tekerlekli Sandalye Basketbolcularının Esenlik Algısı ve Yaşam Doyum Düzeyinin İncelenmesi
}

\author{
Gökmen ÖZEN* \\ Hüseyin DOĞAN** \\ Nurettin KONAR ${ }^{\star * *}$
}

\section{Öz}

$\mathrm{Bu}$ araştırmanın amacı tekerlekli sandalye basketbolcularının algılanan esenlik ve yaşam doyum düzeylerini incelemektir. Araştırmada nicel çalışma deseni kapsamında tarama (survey) yöntemi kullanılmıştır. Araştırmanın örneklemini Türkiye Bedensel Engelliler Federasyonuna bağlı tekerlekli sandalye basketbol kulüplerinde lisanslı 17- 45 yaş aralı̆̆ında 15 kadın 85 erkek olmak üzere toplam 100 bedensel engelli sporcu oluşturmaktadır. Araştırmada katılımcıların esenlik ve yaşam doyum düzeylerini belirlemek için veri toplama aracı olarak "Algılanan Esenlik Ölçeği” ve "Yaşam Doyum Ölçeği” kullanıldı. Araştırmada katılımcılara uygulanan ölçeklerden elde edilen bulgulara göre tekerlekli sandalye basketbolcularının yüksek düzeyde esenlik algısına ( $X=4.17, S S=0.04)$ ve yaşam doyum düzeyine $(X=20.31$, SS $=.57)$ sahip oldukları belirlendi. İstatistiksel analiz sonuçlarına göre algılanan esenlik ve yaşam doyum düzeyinde cinsiyet, yaş ve lisanslı geçen spor yapma süreleri bakımından gruplar arasında her hangi bir anlamlı farklılık olmadığı tespit edildi $(p>.05)$. Araştırma grubunda yer alan katılımcıların fiziksel esenlik düzeyinin $(X=3.62, S S=0.08)$ diğer esenlik boyutlarına göre daha düşük olduğu belirlendi. Bu araştırmanın örnekleminden elde edilen bilgilere dayanarak tekerlekli sandalye basketbol oyuncularının esenlik algısının ve yaşam doyum düzeyinin cinsiyet ve yaş durumlarına göre farklılaşmadığı spor kulüplerine katıldıkları ilk yıllardan itibaren yüksek olduğu ve bu algının ilerleyen yıllar devam ettiği açığa çıkmıştır.

Anahtar kelimeler: Bedensel Engelli, Basketbol, Esenlik, Yaşam Doyumu, Spor.

\section{Investigating The Perceived Wellness And Life Satisfaction Levels of The Wheelchair Basketball Players}

\footnotetext{
Abstract

The objectives of this study were to examine the level of wheelchair basketball players' perceived wellness and life satisfaction. In the study, qualitative research design was used. Research group was consisted of 100

* Ankara Üniversitesi, Sağlık Bilimleri Enstitüsü, Beden Eğitimi ve Spor ABD, gokmenozen44@gmail.com.

** İnönü Üniversitesi, Beden Eğitimi ve Spor Yüksekokulu, Engellilerde Beden Eğitimi ve Spor Eğitimi Bölümü, dogan6606@gmail.com.

*** İnönü Üniversitesi, Beden Eğitimi ve Spor Yüksekokulu, Engellilerde Beden Eğitimi ve Spor Eğitimi Bölümü, nurettin.konar@inonu.edu.tr.
} 
(15 women and 85 men) wheelchair basketball players who aged between 17 and 45 years old, from Turkish Wheelchair Basketball Leagues. In this research, survey model was used. The "Perceived Wellness Scale" and "Satisfaction with Life Scale" were used to measure level of perceived wellness and satisfaction respectively. In data analysis, it was found that wheelchair basketball players had the high level of perceived wellness $(\mathrm{M}=$ $4.17, \mathrm{SD}=0.04)$ and life satisfaction $(\mathrm{M}=20.31, \mathrm{SD}=0.57)$, but there were no significant difference between players in terms of gender, age and the licensed athletic experience $(p>.05)$. Our results revealed that wheelchair basketball players had lower physical wellness $(\mathrm{M}=3.62, \mathrm{SD}=0.08)$ than emotional, spiritual, social, intellectual, and psychological wellness dimensions. According to the data obtained from the sample of this research, it was determined that wheelchair basketball players have the high level of perceived wellness and the level of life satisfaction from the first years when they participated. Their perception and satisfaction have continued in later years and not differ by gender and age.

Keywords: Body handicapped, Basketball, Wellness, Life Satisfaction, Sport.

\section{Giriş}

İnsan, temel fizyolojik ihtiyaçlarını karşıladıktan sonra mutlu ve iyi olmak ister. Mutluluk kavramı, düşünce tarihinin öncül konularından biri olduğu gibi, insanların yaradılışından bugüne arzu ettiği en büyük hedeflerindendir (Ryff \& Singer, 2006). Aristotales, insanoğlunun her şeyden çok istediği ve tüm çabalarının amacı olan mutluluğu, kişinin kendisi için "iyi” olanı gerçekleştirmesi, “iyi olması” olarak tanımlanmıştır (Csikzentmihalyi, 2005; Gökberk, 1985). İyi olmak ise mutlulukla yakından ilişkili ve genel bir manada mutlu olmakla beraber ele alınmıştır. Dünya Sağlık Örgütü (DSÖ) 1940’lardan önce iyi ve sağlıklı olmayı, “herhangi bir hastalık belirtisine sahip olmamak" olarak tanımlanmaktayken, günümüzde ise " yalnız hastalık ve sakatlı̆̆ın olmaması durumu” olarak değil, "kişinin fiziksel, ruhsal ve sosyal olarak tam anlamıyla sağlıklı veya tam bir iyi olma hali” olarak yeniden tanımlanmıştır. Bu yeni tanımda en önemli nokta ise sağlık tanımıyla ortaya çıkan ve kapsamının belirlenmesi beklenen "iyi olma hali” kavramıdır (WHO, 2010; Compton, 2005).

İyi olma hali, kelime olarak İngilizce'de "wellness" ya da "well-being” olarak kullanılırken yerli literatürde bu kavram zindelik, fiziksel uygunluk, iyilik hali kelimelerine karşılık gelmektedir. Literatürde bu farklı terimlere rağmen Karagözoğlu, "esenlik”"terimini terminolojiye kazandırmıştır (Karagözoğlu, 2005). Ülkemizde yapılan benzer çalışmalarda yaygın olarak "esenlik” kelimesi kullanıldığı için çalışmamızda da benzer şekilde "wellness" kelimesi "esenlik" kelimesiyle ifade edildi (Abdulhayoğlu, Kaya \& Konar, 2012).

İnsan sağlığı üzerine geçmişte yapılan tıbbi uygulamalar incelendiğinde tıbbın yalnızca insanların fiziksel ve zihinsel sağlığına yönelik hastalıkları tedavi etmeye odaklanmış olduğu görülmektedir. Günümüzde ise tıp sadece hastalıkları tedavi etmek değil hastalığa neden olan etmenleri ortadan kaldırarak sağlığın korunmasını hedeflemektedir (DSÖ, 2010). Özellikle hastalıkların ortaya çıkmasında veya tedavisinde insanların ruh hali veya psikolojik durumu sağlık açısından oldukça önemli olduğundan kişilerin esenlik ve yaşam kalitesi algısı üzerinde çalışılan bir konudur (Carmona, Giannini, Bergmark \& Cabe, 2010). 
Spor fiziksel yararlarının dışında bireylerin ruhsal durumuna olumlu etki yapan sosyal ve moral edinimler için yapılan hareketler bütünü olarak da tanımlanmaktadır. İnsan bedenini fiziksel yönden geliştirdiği gibi oyunlar, aktiviteler ve yarışmalar vasıtasıyla aynı zamanda insanın karakterini, egosunu, davranış niteliğini, psişik yapısını belirleyen bir bilim dalıdır (Sevil ve ark., 2012). Spor evrensel kültürün bir parçası, dünyada dili, ırkı, dini farklı insanları birleştiren önemli bir araçtır. Bu bağlamda spor her kesimden insanın sağlığının korunmasında esenlik algısının ve yaşam kalitesinin arttırılmasında etkili bir aktivitedir (Akdura, 2007; Saner, 2016).

İnsanlarda hastalık, kaza ve genetik gibi birçok nedenle doğuştan veya sonradan ortaya çıkan engellilik durumu günümüzde milyonlarca insanın yaşam kalitesi ve esenlik algısında olumsuz etkiler yapmaktadır. Genel nüfusta olduğu gibi engelli insanlar içinde sporun fiziksel, zihinsel ve psikolojik yararları bilimsel bir gerçektir (Carmona ve ark., 2010). Engelli insanlar için dünyada sportif çalışmaların ilk olarak 1945 yılında İngiltere'de Aylesbury kentinde Stoke Mandeville Rehabilitasyon Merkezi’nde Dr.Ludwig Guttmann öncülügünde II. Dünya Savaşı’nda şarapnel parçaları ile yaralanmış parapleji hastalarının rehabilitasyonu için sporun kullanılması ile başlamıştır. Engellilerde sporun olumlu etkilerini gören ve daha büyük kitlelere yayılmasını sağlamak amacıyla Dr. Guttmann engellilerin spor etkinliklerinin İngiltere sınırlarının dışına çıkartılıp, uluslararası düzeye getirilmesini önermiştir. Bu girişimler sonucunda engelli spor organizasyonları düzenlenmeye başlamış ve 1960 yılındaki Roma Olimpiyat Oyunları ardından I. Paralimpik Oyunları 21 ülkeden 400 sporcu ve 300 idarecinin katılımı ile gerçekleştirilmiştir (Kalyon, 1997; Rimmer, 2005). En son ondördüncüsü 2012 yılında Londra’ da yapılan yaz oyunlarına 20 spor dalında organizasyona 160 ülkeden 4000 sporcunun katılımıyla gerçekleşti (International Olympic Committe, 2013).

Günümüzde ülkemizde ve dünyada hem sporcu hem de seyirci bakımından engelli sporları içerisinde tekerlekli sandalye basketbol branşı en fazla ilgi duyulan branşlardan biridir. Bu bağlamda araştırmamızın örneklemi tekerlekli sandalye basketbol oyuncuları olarak belirlenmiştir. $\mathrm{Bu}$ örneklem seçimi yapılırken, engelli sporları içerisinde tekerlekli sandalye basketbolunda ülkemizde düzenli yürütülen birden fazla ligin bulunması, sporcu sayısının fazla olması ve kulüplerin sporcularına düzenli antrenman yapma imkânı vermesi göz önüne alınmıştır.

$\mathrm{Bu}$ araştırmanın amacı engelli bireylerin gündelik hayatında veya toplumsal yaşantısında birçok nedenle değişkenlik gösteren esenlik algısına ve yaşam kalitesine sporun yaptığı etkiyi bilimsel bulgularla açığa çıkarmaktı.

\section{YÖNTEM}

\section{Araştırma Yöntemi}

Araştırmada nicel araştırma kapsamında tarama (survey) yöntemi kullanılmıştır. Karasar’a (2012) göre, tarama yöntemi halen var olan bir durumu var olduğu şekliyle betimlemeyi amaçlayan araştırma yaklaşımıdır. Tarama modeli araştırmalarda bilgi toplamayı, bunları değişkenlerle olan ilişkileri yönünden incelemeyi daha kolay hale getirmektedir (Karasar, 2012). 


\section{Araştırmanın Evreni ve Örneklemi}

Araştırmanın evrenini ülkemizde tekerlekli sandalye liglerinde mücadele eden lisanslı sporcular oluşturmaktadır. Araştırmanın örneklemini ise basit seçkisiz örnekleme (Simple Random Sampling) yoluyla belirlenen Malatya, Gaziantep, Samsun, Hatay, Şanlıurfa ve Osmaniye illerinde yaşayan sporcular oluşturmaktadır. Bu illerde yaşayan sporculara gönderilen anketlerden sadece 100 tanesi eksiksiz, tam olarak geri dönüş sağlamıştır.

\section{Veri Toplama Araçları}

\section{Kişisel Bilgi Formu}

Araştırmada hazırlanan kişisel bilgi formunda araştırmaya katılan tekerlekli sandalye basketbol oyuncularının yaş, cinsiyet, sporculuk süresi olmak üzere demografik özelliklerine yönelik sorular bulunmaktadır.

\section{Algılanan Esenlik Ölçeği (AEÖ)}

Algılanan Esenlik Ölçeği bireylerin algıladıkları esenlik düzeylerini belirlemek için Adams ve ark. (1997) tarafından geliştirilmiştir (Adams, Bezner ve Steinhardt, 1997). Ülkemizde güvenilirlik ve geçerliliği Memnun (2006) tarafından yapılarak ölçek Türkçeye uyarlanmıştır. AEÖ altılı likert tipi, 36 maddeden oluşmaktadır. Ölçek 6 alt boyuttan oluşmakta ve her boyut 6 maddeden oluşmaktadır. Ölçekte 2,4,7,11,12,14,17,23,25,29,34 ve 37. maddeler olumsuz yapıda oldukları için tersine puanlanmıştır. Ölçekten toplamda 36 ile 216 arası puan alınabilmektedir. Ölçekte toplamda 144 veya ortalama 4 puanın altı iyilik halinin düşük olduğunu, toplamda 144 veya ortalama 4 puan ve üstü ise iyilik halinin yüksek olduğunu göstermektedir. Bu doğrultuda puanın yükselmesi iyilik halinin de artması anlamına gelmektedir. Memnun’un çalışmasında ölçeğin Cronbach alfa değeri 0.84 olarak bildirilmiştir (Memnun, 2006).

\section{Yaşam Doyum Ölçeği (YDÖ)}

Yaşam doyumunu ölçmek amacıyla geliştirilen ölçek hiç katılmıyorumdan, tamamen katılıyoruma kadar değişen cevaplar içeren 5 maddeli bir ölçektir. Her bir maddeden alınan puanlar 1 ile 7, toplam puan ise 1-35 arasında değişebilmektedir. Ölçekten alınan puan yükseldikçe yaşam doyumunun yükseldiğine işaret eder. Ölçeğin Türkçe geçerlik, güvenirlik çalışması Köker (1991) tarafından yapılmıştır. Köker’in çalışmasında ölçeğin Cronbach alfa değeri 0.85 olarak bildirilmiştir (Köker, 1991).

\section{Verilerin Toplanması}

Araştırmanın amaçlarına ulaşmak, gerekli olan tüm verilerin toplanabilmesi için Algılanan Esenlik Ölçeği ve Yaşam Doyum Ölçeği kullanılmış olup gerekli olan veriler elde edilmiştir. 
Ölçekler Malatya, Gaziantep, Samsun, Hatay, Şanlıurfa ve Osmaniye illerinde tekerlekli sandalye liglerinde mücadele eden lisanslı sporculara dağıtılarak elde edilmiştir.

\section{İstatistiksel Analiz}

Verilerin analizi Tekerlekli Sandalye Basketbol oyuncularına uygulanan anketlerden elde edilen veriler için genel dağılım istatistiklerinden aritmetik ortalama ve standart sapma, en küçük ve büyük değerleri kullanılarak SPSS 17 Trial paket programında analiz edilmiş ve yorumlanmıştır. Verilerin normal dağılım gösterip göstermediği sınamak için "Kolmogorov-Smirnov" normallik analiz testleri yapıldı. Veriler normal dağılım göstermediği için non-parametrik testler kullanıldı. Veriler katılımcıların cinsiyetlerine, yaş ve spor yapma yıllarına göre karşılaştırılmıştır. Cinsiyet değişkenine göre algılanan esenlik ve yaşam doyum puanlarının karşılaştırılmasında iki ortalama arasındaki farkın önemliliği için Mann-Whitney U testi, spor yapma yılları değişkenine göre çoklu karşılaştırmalar için Kruskal-Wallis H testi yapıldı. Araştırmada anlamlılık düzeyi olarak $p<.05$ olarak kabul edildi.

\section{BULGULAR}

Araştırmaya katılan gönüllülerin demografik bilgileri tablo 4.1 de sunuldu.

Tablo I. Araştırmaya katılan gönüllülerin demografik bilgileri.

\begin{tabular}{lccccccc}
\hline Değişken & Grup & N & $\%$ & Min & Max & $\overline{\mathbf{X}}$ & SS \\
\hline \multirow{3}{*}{ Yaş (Yil) } & $16-25$ & 32 & 32 & & & & \\
& $26-35$ & 32 & 32 & 17 & 45 & 30,68 & 7,11 \\
& $36-45$ & 36 & 36 & & & & \\
Spora Yapma Süresi (Yll) & $1-5$ & 33 & 33 & & & & \\
& $6-10$ & 37 & 37 & 1 & 24 & 8,62 & 5,77 \\
& $11-15$ & 20 & 20 & & & & \\
Cinsiyet & $15+$ & 10 & 10 & & & & \\
& Kadın & 15 & 15 & & & & \\
\hline
\end{tabular}

Araştırmaya katılan tekerlekli sandalye basketbolcuları 15 kadın ve 85 erkek olmak üzere toplam 100 kişidir. Katılımcıların yaşı en genç sporcu 17 en yaşlı sporcu ise 45 yaşında olmak üzere ortalama 30.68 yıldır. Katılımcıların tekerlekli sandalye basketbolunda lisanslı olarak spor yaptığ süre ise ortalama 8.62 yıldır. 
Tablo 2. Tekerlekli sandalye basketbolcularının algılanan esenlik ölçeği puanları.

\begin{tabular}{lcccccc}
\hline Esenlik Boyutları & N & Toplam Puan Ort. & $\bar{X}$ & SS & Min & Max \\
\hline Fiziksel & 100 & 21,72 & 3,62 & 0,08 & 2,17 & 6,00 \\
\hline Spritüel & 100 & 26,80 & 4,47 & 0,08 & 2,66 & 6,00 \\
\hline Psikolojik & 100 & 24,11 & 4,02 & 0,06 & 2,67 & 6,00 \\
\hline Sosyal & 100 & 26,69 & 4,45 & 0,07 & 2,33 & 6,00 \\
\hline Duygusal & 100 & 26,38 & 4,40 & 0,07 & 2,17 & 5,33 \\
\hline Entelektüel & 100 & 24,53 & 4,09 & 0,06 & 2,33 & 6,00 \\
\hline Toplam & 100 & 150,23 & 4,17 & 0,04 & 3,19 & 5,31 \\
\hline
\end{tabular}

Araştırmaya katılan tekerlekli sandalye basketbolcularının AEÖ maddelerine verdikleri yanıtlara göre genel toplamda ölçek puan ortalamalarının 150.23 puan olduğu madde sayısı dikkate alındığında ise 4.17 puan ortalamasına sahip oldukları tespit edildi. Ölçek alt boyutlarına göre en düşük puan ortalaması 3.62 puanla Fiziksel esenlik boyutunda olduğu, en yüksek puan ortalamasının ise 4.47 Spritüel esenlik boyutunda olduğu belirlendi. Ölçek için yapılan puan hesaplamasına göre ortalama 4 puan üzerinde olan Spritüel, Psikolojik, Sosyal, Duygusal ve Entelektüel esenlik boyutlarında ve genel toplamda katılımcıların yüksek esenlik düzeyinde olduğu tespit edildi.

Tablo 3. Tekerlekli sandalye basketbolcularının cinsiyetlerine göre algılanan esenlik ölçeği alt boyut puan ortalamalarının karşılaştırılması.

\begin{tabular}{|c|c|c|c|c|c|c|c|c|}
\hline Esenlik Boyutları & Cinsiyet & $\mathrm{N}$ & $\bar{X}$ & SS & Min & $\operatorname{Max}$ & $\mathrm{U}$ & $p$ \\
\hline \multirow{2}{*}{ Fiziksel } & Kadın & 15 & 3,36 & 0,70 & 2,17 & 6,00 & \multirow{2}{*}{515} & \multirow{2}{*}{$.236^{\mathrm{AD}}$} \\
\hline & Erkek & 85 & 3,35 & 0,76 & 2,17 & 4,50 & & \\
\hline \multirow{2}{*}{ Spritüel } & Kadın & 15 & 4,58 & 0,85 & 2,67 & 5,50 & \multirow{2}{*}{536} & \multirow{2}{*}{$.328^{\mathrm{AD}}$} \\
\hline & Erkek & 85 & 4,45 & 0,74 & 2,83 & 6,00 & & \\
\hline \multirow{2}{*}{ Psikolojik } & Kadın & 15 & 3,94 & 0,47 & 3,33 & 4,83 & \multirow{2}{*}{587} & \multirow{2}{*}{$.621^{\mathrm{AD}}$} \\
\hline & Erkek & 85 & 4,03 & 0,64 & 2,67 & 6,00 & & \\
\hline \multirow{2}{*}{ Sosyal } & Kadın & 15 & 4,51 & 0,59 & 3,33 & 5,33 & \multirow{2}{*}{601} & \multirow{2}{*}{$.723^{\mathrm{AD}}$} \\
\hline & Erkek & 85 & 4,44 & 0,70 & 2,33 & 6,00 & & \\
\hline \multirow{2}{*}{ Duygusal } & Kadın & 15 & 4,37 & 0,79 & 2,50 & 5,50 & \multirow{2}{*}{627} & \multirow{2}{*}{$.919^{\mathrm{AD}}$} \\
\hline & Erkek & 85 & 4,40 & 0,71 & 2,17 & 5,83 & & \\
\hline \multirow{2}{*}{ Entelektüel } & Kadın & 15 & 4,17 & 0,69 & 3,00 & 5,17 & \multirow{2}{*}{569} & \multirow{2}{*}{$.510^{\mathrm{AD}}$} \\
\hline & Erkek & 85 & 4,07 & 0,64 & 2,33 & 6,00 & & \\
\hline \multirow{2}{*}{ Toplam } & Kadin & 15 & 4,15 & 0,38 & 3,28 & 4,58 & \multirow{2}{*}{607} & \multirow{2}{*}{$.772^{\mathrm{AI}}$} \\
\hline & Erkek & 85 & 4,18 & 0,39 & 3,19 & 5,31 & & \\
\hline
\end{tabular}

AD: Anlamlı değil, $p>.05$ 
Araştırmaya katılan tekerlekli sandalye basketbolcularının Tablo 3 'de sunulan cinsiyet değişkenine göre AEÖ alt boyut puan ortalamaları için yapılan Mann-Whitney U testi sonuçlarına göre ölçeğin tüm alt boyutlarında kadınlar ve erkekler arasında istatistiksel olarak anlamlı bir fark yoktur $(p>.05)$.

Tablo 4. Tekerlekli sandalye basketbolcularının algılanan esenlik ölçeği alt boyut puan ortalamalarının yaş gruplarına göre karşılaştırılması.

\begin{tabular}{|c|c|c|c|c|c|c|c|c|}
\hline Esenlik Boyutları & Yaş & $\mathbf{N}$ & $\bar{X}$ & SS & Min & Max & Chi- Square & $p$ \\
\hline \multirow{3}{*}{ Fiziksel } & $16-25$ & 32 & 3,67 & 0,75 & 2,33 & 5,33 & \multirow{3}{*}{2,428} & \multirow{3}{*}{, $297 \mathrm{AD}$} \\
\hline & $26-35$ & 32 & 3,43 & 0,69 & 2,17 & 4,83 & & \\
\hline & $36-45$ & 36 & 3,75 & 0,82 & 2,17 & 6,00 & & \\
\hline \multirow{3}{*}{ Spritüel } & $16-25$ & 32 & 4,54 & 0,77 & 2,67 & 6,00 & \multirow{3}{*}{3,070} & \multirow{3}{*}{, $216^{\mathrm{AD}}$} \\
\hline & $26-35$ & 32 & 4,23 & 0,77 & 2,83 & 5,67 & & \\
\hline & $36-45$ & 36 & 4,61 & 0,68 & 3,33 & 5,83 & & \\
\hline \multirow{3}{*}{ Psikolojik } & $16-25$ & 32 & 4,11 & 0,66 & 2,83 & 6,00 & \multirow{3}{*}{1,490} & \multirow{3}{*}{, $475^{\mathrm{AL}}$} \\
\hline & $26-35$ & 32 & 3,97 & 0,54 & 3,00 & 5,33 & & \\
\hline & $36-45$ & 36 & 3,98 & 0,65 & 2,67 & 5,50 & & \\
\hline \multirow{3}{*}{ Sosyal } & $16-25$ & 32 & 4,59 & 0,62 & 3,33 & 6,00 & \multirow{3}{*}{1,250} & \multirow{3}{*}{, $535^{\mathrm{AL}}$} \\
\hline & $26-35$ & 32 & 4,40 & 0,71 & 2,50 & 5,67 & & \\
\hline & $36-45$ & 36 & 4,37 & 0,71 & 2,33 & 5,50 & & \\
\hline \multirow{3}{*}{ Duygusal } & $16-25$ & 32 & 4,60 & 0,59 & 2,50 & 5,67 & \multirow{3}{*}{5,553} & \multirow{3}{*}{, $062^{\mathrm{AL}}$} \\
\hline & $26-35$ & 32 & 4,31 & 0,84 & 2,17 & 5,67 & & \\
\hline & $36-45$ & 36 & 4,29 & 0,69 & 2,67 & 5,83 & & \\
\hline \multirow{3}{*}{ Entelektüel } & $16-25$ & 32 & 3,90 & 0,71 & 2,33 & 5,67 & \multirow{3}{*}{4,394} & \multirow{3}{*}{, $111^{\mathrm{AD}}$} \\
\hline & $26-35$ & 32 & 4,13 & 0,63 & 2,83 & 5,17 & & \\
\hline & $36-45$ & 36 & 4,23 & 0,56 & 3,33 & 6,00 & & \\
\hline \multirow{3}{*}{ Toplam } & $16-25$ & 32 & 4,24 & 0,36 & 3,28 & 5,31 & \multirow{3}{*}{2,445} & \multirow{3}{*}{$295^{\mathrm{AD}}$} \\
\hline & $26-35$ & 32 & 4,08 & 0,43 & 3,19 & 5,03 & & \\
\hline & $36-45$ & 36 & 4,20 & 0,35 & 3,53 & 5,25 & & \\
\hline
\end{tabular}

AD: Anlamlı değ il, $p>.05$

Araştırmaya katılan tekerlekli sandalye basketbolcularının Tablo 4 'de sunulan yaş gruplarına göre AEÖ alt boyut puan ortalamaları için yapılan Kruskal-Wallis H testi sonuçlarına göre ölçeğin tüm alt boyutlarında ve toplam skorlarında yaş grupları arasında istatistiksel olarak anlamlı bir fark yoktur $(p>.05)$. 
Tablo 5. Tekerlekli sandalye basketbolcularının spor yapma yıllarına göre algılanan esenlik ölçeği alt boyut puan ortalamalarının karşılaştırılması.

\begin{tabular}{|c|c|c|c|c|c|c|c|c|}
\hline Esenlik Boyutları & Spor Yaptığı Yıl & $\mathbf{N}$ & $\bar{X}$ & SS & Min & $\operatorname{Max}$ & Chi-Square & $p$ \\
\hline \multirow{4}{*}{ Fiziksel } & $1-5$ & 33 & 3,77 & 0,69 & 2,67 & 5,33 & \multirow{4}{*}{4,362} & \multirow{4}{*}{, $225^{\mathrm{AD}}$} \\
\hline & $6-10$ & 37 & 3,49 & 0,75 & 2,17 & 5,33 & & \\
\hline & $11-15$ & 20 & 3,45 & 0,57 & 2,50 & 4,50 & & \\
\hline & $15+$ & 10 & 3,97 & 1,15 & 2,17 & 6,00 & & \\
\hline \multirow{4}{*}{ Spritüel } & $1-5$ & 33 & 4,44 & 0,79 & 3,33 & 6,00 & \multirow{4}{*}{3,132} & \multirow{4}{*}{, $372^{\mathrm{AD}}$} \\
\hline & $6-10$ & 37 & 4,52 & 0,71 & 2,67 & 5,50 & & \\
\hline & $11-15$ & 20 & 4,27 & 0,80 & 2,83 & 5,47 & & \\
\hline & $15+$ & 10 & 4,71 & 0,65 & 4,00 & 5,83 & & \\
\hline \multirow{4}{*}{ Psikolojik } & $1-5$ & 33 & 4,10 & 0,48 & 2,67 & 6,00 & \multirow{4}{*}{1,838} & \multirow{4}{*}{$607^{\mathrm{AD}}$} \\
\hline & $6-10$ & 37 & 3,92 & 0,63 & 2,83 & 5,17 & & \\
\hline & $11-15$ & 20 & 4,10 & 0,47 & 3,00 & 5,50 & & \\
\hline & $15+$ & 10 & 3,95 & 0,44 & 3,33 & 4,67 & & \\
\hline \multirow{4}{*}{ Sosyal } & $1-5$ & 33 & 4,61 & 0,63 & 3,33 & 6,00 & \multirow{4}{*}{2,579} & \multirow{4}{*}{, $461^{\mathrm{AD}}$} \\
\hline & $6-10$ & 37 & 4,36 & 0,67 & 3,17 & 5,67 & & \\
\hline & $11-15$ & 20 & 4,43 & 0,82 & 2,33 & 5,33 & & \\
\hline & $15+$ & 10 & 4,27 & 0,85 & 2,50 & 5,50 & & \\
\hline \multirow{4}{*}{ Duygusal } & $1-5$ & 33 & 4,42 & 0,63 & 3,00 & 5,67 & \multirow{4}{*}{,278 } & \multirow{4}{*}{$964^{\mathrm{AD}}$} \\
\hline & $6-10$ & 37 & 4,37 & 0,80 & 2,17 & 5,67 & & \\
\hline & $11-15$ & 20 & 4,34 & 0,81 & 2,67 & 5,67 & & \\
\hline & $15+$ & 10 & 4,53 & 0,59 & 3,67 & 5,83 & & \\
\hline \multirow{4}{*}{ Entelektüel } & $1-5$ & 33 & 3,97 & 0,70 & 2,33 & 5,67 & \multirow{4}{*}{4,285} & \multirow{4}{*}{, $232^{\mathrm{AD}}$} \\
\hline & $6-10$ & 37 & 4,21 & 0,52 & 3,00 & 5,17 & & \\
\hline & $11-15$ & 20 & 4,00 & 0,77 & 2,83 & 6,00 & & \\
\hline & $15+$ & 10 & 4,20 & 0,55 & 3,33 & 5,00 & & \\
\hline \multirow{4}{*}{ Toplam } & $1-5$ & 33 & 4,15 & 0,36 & 3,28 & 4,81 & \multirow{4}{*}{3,245} & \multirow{4}{*}{, $355^{\mathrm{AD}}$} \\
\hline & $6-10$ & 37 & 4,10 & 0,49 & 3,19 & 5,25 & & \\
\hline & $11-15$ & 20 & 4,27 & 0,35 & 3,64 & 4,64 & & \\
\hline & $15+$ & 10 & 4,17 & 0,38 & 3,19 & 5,31 & & \\
\hline
\end{tabular}

AD: Anlamlı değil, $p>.05$ 
Araştırmaya katılan tekerlekli sandalye basketbolcularının Tablo 5 'te sunulan spor yapma sürelerine göre AEÖ alt boyut puan ortalamaları için yapılan Kruskal-Wallis H testi sonuçlarına göre ölçeğin tüm alt boyutlarında ve toplam skorlarında spor yapma süreleri arasında istatistiksel olarak anlamlı bir fark yoktur $(p>.05)$.

Tablo 6. Tekerlekli sandalye basketbolcularının yaşam doyum ölçeği puanları.

\begin{tabular}{lccccc}
\hline Ölçek Maddeleri & $\mathbf{N}$ & $\bar{X}$ & SS & Min & Max \\
\hline Yaşamım birçok açıdan idealimdekine yakın & 100 & 3,63 & 0,18 & 1 & 7 \\
\hline Yaşam koşullarım mükemmel & 100 & 4,45 & 0,15 & 1 & 7 \\
\hline Yaşamımdan memnunum & 100 & 4,51 & 0,16 & 1 & 7 \\
\hline Şu ana kadar, yaşamdan istediğim önemli şeyleri elde ettim & 100 & 4,36 & 0,17 & 1 & 7 \\
\hline Eğer yaşamımı yeni baştan yaşayabilsem, hiçbir şeyi değiştirmezdim & 100 & 3,36 & 0,19 & 1 & 7 \\
\hline Genel Toplam & 100 & 20,31 & 0,57 & 7 & 35 \\
\hline
\end{tabular}

Araştırmaya katılan tekerlekli sandalye basketbolcularının Tablo 6 'da sunulan YDÖ maddelerine verdikleri yanıtlara göre genel toplamda ölçek puan ortalamalarının 20,43 puan olduğu tespit edildi. Ölçek maddelerine göre en düşük puan ortalaması 3.36 puanla "Eğer yaşamımı yeni baştan yaşayabilsem, hiçbir şeyi değiştirmezdim" maddesinde en yüksek puan ortalamasının ise 4.51 puanla "Yaşamımdan memnunum" maddesinde olduğu belirlendi.

Tablo 7. Tekerlekli sandalye basketbolcularının cinsiyetlerine göre yaşam doyum ölçeği puan ortalamalarının karşılaştırılması.

\begin{tabular}{llccccccc}
\hline Değișken & Grup & N & $\bar{X}$ & SS & Min & Max & U & $p$ \\
\hline \multirow{2}{*}{ Cinsiyet } & Kadın & 15 & 18,07 & 3,73 & 10 & 29 & & \\
& Erkek & 85 & 20,71 & 3,73 & 7 & 35 & 463 & $.09^{\mathrm{AD}}$ \\
\hline
\end{tabular}

AD: Anlamlı değil, $p>.05$

Araştırmaya katılan tekerlekli sandalye basketbolcularının Tablo 7 'de sunulan cinsiyet değişkenine göre YDÖ puan ortalamaları kadınlarda 18.07 ve erkeklerde 20.71 puan olduğu tespit edildi. Mann-Whitney U testi sonuçlarına göre kadınlar ve erkekler arasında istatistiksel olarak anlamlı bir fark yoktur $(p>.05)$. 
Tablo 8. Tekerlekli sandalye basketbolcularının yaşam doyum ölçeği puan ortalamalarının lisanslı spor yaptığı yıl ve yaş gruplarına göre karşılaştırılması.

\begin{tabular}{lcccccccc}
\hline Değişken & Grup & N & $\bar{X}$ & SS & Min & Max & Chi-Square & $p$ \\
\hline \multirow{3}{*}{ Yaş (Yil) } & $16-25$ & 32 & 21,19 & 6,03 & 12 & 35 & & \\
& $26-35$ & 32 & 20,13 & 5,28 & 10 & 31 &, 605 &, $739^{\mathrm{AD}}$ \\
& $36-45$ & 36 & 19,69 & 5,85 & 7 & 35 & & \\
\hline \multirow{3}{*}{ Spor Yaptığı Yil } & $1-5$ & 33 & 20,73 & 5,62 & 12 & 35 & & \\
& $6-10$ & 37 & 20,11 & 5,47 & 10 & 31 &, 351 & \\
& $11-15$ & 20 & 20,25 & 7,06 & 7 & 35 & & \\
& $15+$ & 10 & 19,82 & 4,76 & 16 & 29 & & \\
\hline
\end{tabular}

AD: Anlamlı değil, $p>.05$

Araştırmaya katılan tekerlekli sandalye basketbolcularının Tablo 8 'de sunulan lisanslı spor yaptıkları yıl ve yaş gruplarına göre YDÖ puan ortalamaları için yapılan Kruskal-Wallis H testi sonuçlarına göre ölçeğin toplam skorlarında hem lisanslı spor yaptıkları yıl hemde yaş grupları arasında istatistiksel olarak anlamlı bir fark yoktur $(p>.05)$.

\section{TARTIŞMA}

İnsanlarda hastalık, kaza ve genetik gibi birçok nedenle doğuştan veya sonradan ortaya çıkan engellilik durumu günümüzde milyonlarca insanın yaşam kalitesi ve esenlik algısında olumsuz etkilenmesine neden olmaktadır. Engelli bireyler için spor yapmak özellikle bireysel veya grup halinde fiziksel ve psikolojik sağlı̆̆ın desteklenmesi açısından oldukça önemlidir. Engelli sporları içerisinde tekerlekli sandalye basketbolu en popüler ve en fazla sporcunun mücadele ettiği branşlardan biridir. Bu bağlamda araştırmada tekerlekli sandalye basketbol liglerinde mücadele eden 15 kadın ve 85 erkek sporcunun algılanan esenlik ve yaşam doyum düzeyleri cinsiyet, yaş ve lisanslı spor yaptığı yıllara göre incelendi.

Araştırmaya katılan tekerlekli sandalye basketbolcularının AEÖ toplam puan ortalaması 4.17£0.04 olarak tespit edilmiştir. Bu sonuç katılımcıların yüksek düzeyde esenlik algısına sahip olduklarını göstermektedir. AEÖ ölçeğinden elde edilen skorlar esenlik alt boyutları bakımından incelendiğinde fiziksel esenlik algısının $3.62 \pm 0.08$ puan ortalamasıyla en düşük, diğer tüm boyutlarda ise ortalama puanın 4 puan üzerinde olduğu tespit edildi. Esenlik alt boyutları içerisinde katılımcıların en yüksek esenlik düzeyinin $4.47 \pm 0.08$ puan ortalaması ile sprituel (manevi) esenlik boyutunda olduğu belirlendi. AEÖ alt boyutlarında ortalaması 4 puanın altında kalan fiziksel esenlik düzeyinin tekerlekli sandalye basketbolcuların düşük olduğunu göstermektedir. Bu sonuç 
engelli bireylerin fiziksel sağlık durumları dikkate alındığında diğer boyutlara göre beklen bir sonuçtur. Literatürde yapılan araştırmalarda Doğan ve Yıldırım (2006) ile Abdulhayoğlu ve ark. (2012) yaptıkları çalışmalarında düzenli fiziksel aktiviteye katılan insanların esenlik düzeyinin yüksek olduğunu tespit etmişlerdir. Bu çalışmada elde edilen bulgularda düzenli fiziksel aktivite yapan engelli bireylerinde esenlik düzeyinin yüksek olduğunu göstermektedir. Bu bağlamda araştırmanın sonuçları diğer çalışmalarla benzer niteliktedir.

Araştırmada AEÖ’ den elde edilen bulgular cinsiyet değişkeni açısından incelendiğinde ölçek skor ortalaması kadınlarda 4.15 erkeklerde 4.18 puan olarak hesaplanmıştır. Bu sonuç hem erkeklerin hem de kadınların yüksek esenlik algısına sahip olduklarını göstermektedir. Ancak tekerlekli sandalye basketbolcularında cinsiyet değişkeni bakımından esenlik algısında anlamlı bir farklılık görülmedi $(p>.05)$. Literatürde yapılan araştırmalarda Memnun (2006) 144 beden eğitimi öğretmenine AEÖ uyguladığı çalışmasında bütün esenlik alt boyutları açısından beden eğitimi öğretmenlerinde kadınlarla erkekler arasında anlamlı farklılık bulunmamıştır. $\mathrm{Bu}$ sonuç araştırmamızın sonuçlarıyla benzerlik göstermektedir. Ancak Aşçı (2002), 995 üniversite öğrencisi üzerinde yaptığı bir araştırmada cinsiyet değişkenine göre erkek öğrencilerin bayanlara göre anlamlı şekilde yüksek esenliğe sahip olduğunu bulmuştur. Bu durumun araştırmamızda hem her iki grupta da esenlik algısının yüksek olmasından hem de spor yapmanın cinsiyete bağlı fiziksel gelişimde farklılıklar göstermesine rağmen psikolojik olarak kadınlarda ve erkeklerde aynı etkiyi yaratmasından kaynaklandığı düşünülmektedir. AEÖ alt boyutları bakımından ölçek skorları incelendiğinde fiziksel esenlik boyutunda hem erkeklerde $(3.35 \pm 0.76)$ hem de kadınlarda (3.36 \pm 0.70$)$ düşük düzeyde olduğu görüldü. Diğer alt boyutlarda ise her iki grupta esenlik algısının yüksek düzeyde ( $>4$ puan) olduğu belirlendi.

Araştırmada AEÖ’ den elde edilen bulgular katılımcıların yaş aralıklarına göre incelendiğinde 16-25, 2635 ve 36-45 yaş aralığındaki katılımcıların genel esenlik düzeyinin ölçek skorlarına göre ortalama 4 puanın üzerinde olduğu tespit edilmiştir. Yaş grupları arasında ölçekten alınan puan ortalamaları karşılaştırıldığında gruplar arasında istatistiksel olarak anlamlı bir farklılık olamadığı görüldü $(p>.05)$. Bu sonuç TS basketbolcularının her yaş aralığında yüksek esenlik düzeyine sahip olduklarını göstermektedir. Elde edilen bulgular esenlik alt boyutları bakımından incelendiğinde tüm yaş gruplarında fiziksel esenlik algısının ortalama 4 puanın altında olduğu ve bu boyutta yüksek esenlik algısına sahip olmadıkları belirlendi. Araştırmaya katılan sporcuların yaş aralıklarına göre tüm alt boyutlar için yapılan istatistikî analiz sonuçları esenlik boyutlarında anlamlı bir farklılık olmadığını açığa çıkardı. Bu sonucun TS basketbolu ile ilgilenen bedensel engellilerin farklı yaş grupları ile birlikte antrenman alanında ya da sosyal hayatta benzer çevre koşullarında kaynaklandığı düşünülmektedir.

Araştırmaya katılan tekerlekli sandalye basketbolcuların lisanslı olarak spor yaptıkları süre açısından algılanan esenlik düzeyi incelendiğinde; AEÖ skor ortalamalarının 1-5 yıl aralığında olanlarda $4.15 \pm 0.36$, 6-10 yıl aralığında olanlarda 4.10 $\pm 049,11-15$ yıl aralığında olanlarda $4.27 \pm 0.35,15$ yıl ve üzerinde olanlarda ise $4.17 \pm 0.38$ olduğu tespit edildi. Bu sonuç katılımcıların spora başladıkları ilk yıllardan itibaren yüksek düzeyde esenlik algısına sahip 
olduklarını göstermektedir. Söğüt (2006), bedensel engelliler üzerine yaptığı çalışmada, düzenli olarak spor yapan bedensel engelliler ile spor yapmayan bedensel engelliler karşılaştırıldığında spor yapmanın engellilerin sosyalleşmeleri üzerinde etkili olduğunu sonucuna varmıştır. Ayrıca Szabo (2003) çalışmasında egzersizin psikolojik sıkıntı ve esenlik üzerine pozitif etki yaptığını belirtmiştir. Bu bağlamda literatürde yapılan çalışmalar ve bu araştırmanın bulguları düzenli spor yapmanın engellerinin esenlik düzeylerinin yüksek olmasını sağladığı ortaya çıkarmaktadır.

Araştırmaya katılan tekerlekli sandalye basketbolcularına uygulanan YDÖ 'den elde edilen sonuçlara göre ölçek skor ortalamasının $20.43 \pm 0.58$ puan olduğu tespit edildi. Ölçekte yer alan

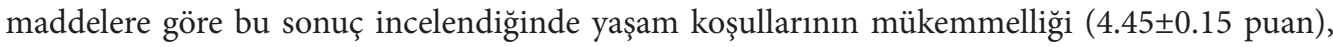
yaşantıdan memnuniyet $(4.51 \pm 016$ puan) ve şu ana kadar yaşamdan istenilen önemli şeylerin elde edilmesi $(4.36 \pm 0.17$ puan) maddelerinde ortalama yaşam doyumunun yüksek olmasına rağmen yaşamın ideallere yakınlığ 1 ( $3.63 \pm 0.18$ puan) ve yaşamı yeni baştan değiştirme ( $3.36 \pm 0.19$ puan) maddelerinde yaşam doyumu skor ortalamalarının düşük olduğu belirlendi. Bu düşük skor ortalamasına sahip maddelerde ölçeğin genel ortalamasının düşmesine neden olmuştur. Ancak araştırmaya katılan bireylerin fiziksel olarak engelli oldukları dikkate alındığında "Eğer yaşamımı yeni baştan yaşayabilseydim hiçbir şeyi değiştirmezdim" maddesinde mevcut engellilik durumlarını ortadan kaldırmak açısından bir değişiklik isteğinin olma olasılı̆̆ı bu maddenin en düşük skor ortalamasına sahip olmasına neden olduğu düşünülmektedir. Ayrıca "Yaşamım birçok açıdan idealimdekine yakın" maddesinin genel ortalamadan düşük çıkması katılımcıların sporcu olması nedeniyle sporun ruhu gereği yüksek hedef ve ideallere sahip olunmasından kaynaklandığı düşünülmektedir. Literatürde Kaya (2013) tarafından çalışma hayatında 122 (38 kadın, 84 erkek) bedensel engelli bireyin yaşam doyum düzeylerini incelediği çalışmada YDÖ puan ortalamasının 15.05 olarak tespit etmiştir. Bu sonuç araştırmamıza katılan tekerlekli sandalye basketbolcularının YDÖ puan ortalamalarıyla (YDÖ ort: 20.43 puan) karşılaştırıldığında daha yüksek yaşam doyum düzeyine sahip oldukları görülmektedir. Sarıdemir (2015) 'in çalışmasında ise 305 öğretmene uygulanan YDÖ puan ortalamasının 21.18 puan ile araştırma grubumuzun ortalamasına yakın bir değer olduğu görülmektedir.

Tekerlekli sandalye basketbolcularının yaşam doyum düzeyleri cinsiyet, yaş ve lisanslı spor yapma sürelerine göre karşılaştırıldığında istatistiksel olarak anlamlı bir farklılık bulunmamıştır $(p<$.05). Kaya (2013) araştırmasında çalı̧an bedensel engellilerde yaşam doyum düzeyi bakımından araştırmamızın bulgularılya benzer şekilde cinsiyet ve yaş grupları arasında anlamlı bir farklılık bulunmamıştır. Sarıdemir (2015) tarafından yapılan çalışmada ise 182 kadın ve 123 erkek öğretmene uygulanan YDÖ sonuçlarına göre de cinsiyet grupları arasında istatistiksel olarak farklılık olmadığı belirlenmiştir. Bu bilgilere dayanarak cinsiyet yaşam doyumunda farklılı̆ga neden olan bir faktör değildir. Literatürde yaş gruplarına göre yaşam doyum düzeyinin değerlendirildiği Acar (2010), Ünal ve Şahin (2013) ve Taş (2011) tarfından yapılan çalışmalar incelendiğinde araştırmamızın sonuçlarıyla benzer şekilde yaşam doyum düzeyinin yaşa bağlı farklılık göstermediğini belirtilmiştir. 
Yapılan araştırmalarda, yaşam doyumuna etki eden faktörler içinde, yaşanılan kültür, sosyal çevre, benlik saygısı, problem çözme becerisi, fiziksel aktivite düzeyi, maddi olanaklar, fiziksel ve psikolojik sağlık, evlilik gibi birçok etkenin varlığı rapor edilmiştir (Cheng \& Furnham, 2003; Dockery, 2004; Şah, 2005). Bu araştırmaya katılan gönüllülerinde yaşadıkları bölge, sportif etkinlik türü, sosyal çevre gibi birçok açıdan benzer bir ortamda yaşamları bu değişkenler bakımından yaşam doyumlarına bir farklılık olmamasının nedeni olarak düşünülmektedir. Literatürde tekerlekli sandalye kullanan bireylerde fonksiyonel kapasitenin artması yaşam kalitesini olumlu yönde etkilerken, omuz ağrısındaki artış yaşam kalitesini azalttığı belirtilmiştir (Üstünkaya, 2005). Başka bir çalışmada Muraki, Tsunawake, Hiramatsu ve Yamasaki (2000) 169 erkek spinal kord yaralanmalı kişi üzerinde yaptıkları çalışmada, deneklerin spora katılımının yüksek olduğu dönemlerde depresyonun düşük olduğunu tespit etmiş ve egzersizin sıklı̆̆1 arttıkça psikolojik faydalarının da arttı̆̆ını ifade etmiştir. Yazıcı (2012) ise çalışmasında ampute bireylerde spor yapmanın yaşam kalitesini artırdığını bildirmiştir. Bu bilgiler ve araştırmamızın bulguları doğrultusunda düzenli fiziksel aktivite ve spor sağlıklı bireylerde olduğu gibi bedensel engelli bireylerinde yaşam doyum düzeyine katkı sağlamaktadır.

\section{SONUÇ VE ÖNERILER}

Araştırma kapsamında ülkemizde tekerlekli sandalye basketbol liglerinde mücadele eden 100 sporcuya uygulanan AEÖ ve YDÖ'nden elde edilen verilere göre; düzenli spor yapan katılımcıların yüksek düzeyde esenlik algısına ve yaşam doyumuna sahip oldukları tespit edilmiştir. Esenlik algısı alt boyutları bakımından bedensel engelli sporcuların fiziksel esenlik düzeyinin diğer boyutlara göre daha düşük olduğu ortaya çıkmıştır. Yaşam doyum düzeylerini belirlemek amacıyla kullanılan YDÖ’nde bulunan maddelere verilen yanıtlara göre genel olarak yaşamlarından memnun olmalara rağmen katılımcıların "Eğer yaşamımı yeni baştan yaşayabilsem, hiçbir şeyi değiştirmezdim” maddesinin en düşük puan ortalamasına sahip olduğu yani yaşamlarında bazı şeyleri değiştirme isteğinde oldukları belirlenmiştir.

Sonuç olarak bu araştırmada tekerlekli sandalye basketbolcularının esenlik algısının ve yaşam doyum düzeyinin cinsiyet ve yaş durumlarına göre değişmeksizin spor kulüplerine katıldıkları ilk yıllardan itibaren yüksek olduğu ve bu algının uzun yıllar devam ettiği açığa çıkmıştır. 


\section{KAYNAKLAR}

Abdulhayoğlu, B., Kaya, B., \& Konar, N. (2012). Masa tenisi oyuncularının esenlik algıları. Selçuk University Journal of Physical Education and Sport Science, 14(2), 268-272.

Acar, B. (2010). Akademisyenlerde yaşam doyumu, iş doyumu ve meslekî tükenmişlik düzeylerinin belirlenmesine yönelik bir araştırma. Yüksek Lisans Tezi, Uşak Üniversitesi, Uşak.

Adams, T., Bezner, J., \& Steinhardt, M. (1997). The conceptualization and measurement of perceived wellness: Integrating balance across and within dimensions. American Journal of Health Promotion, 11(3), 208-218.

Akdura, E., (2007), Bedensel engelli basketbol tekerlekli sandalye liglerinde aktif spor yapan basketbolcuların toplumsal yasama uyumlarında sporun etkisinin araştırılması. Yüksek Lisans Tezi. Dumlupınar Üniversitesi, Kütahya.

Asçı, F. H. (2002). An investigation of age and gender differences in physical selfconcept among Turkish late adolescents. Adolescence, 37(146), 365-371.

Carmona, R. H., Giannini, M., Bergmark, B., \& Cabe, J. (2010). The surgeon general's call to action to improve the health and wellness of persons with disabilities: historical review, rationale, and implications 5 years after publication. Disability and Health Journal, 3(4), 229-232.

Cheng, H., \& Furnham, A. (2003). Personality, self-esteem, and demographic predictions of happiness and depression. Personality and Individual Differences, 34(6), 921-942.

Compton, C. W. (2005). Introduction to Positive Psychology. Belmont,CA, US: Thomson Wadsworth.

Csikzentmihalyi, M. (2005), Akış -Mutluluk Bilimi-, çev. Semra Kunt Akbaş, Ankara: HYB Yayıncılık.

Diener, E., Emmons, R.A., Larsen, R.J. \& Griffin, S. (1985). The satisfaction with life scale. Journal of Personality Assessment, 49(19), 71-75.

Dockery, A. M. (2004). Happiness, life satisfaction and the role of work: Evidence from two Australian surveys. Unpublished Mimeo.

Doğan, T. \& Yıldırım, İ. (2006). Üniversite öğrencilerinin iyilik halinin "arkadaşlık" ve "sevgi" boyutlarının incelenmesi. Eurasian Journal of Educational Research, 24, 77-86.

Gökberk, M. (1985), Felsefe Tarihi, İstanbul: Remzi Kitabevi.

International Olympic Committe, (2013). Factsheet London 2012, Update Facts \& Figures, Swetzerland: Press Office.

Kalyon, A. T. (1997). Özürlülerde Spor, Ankara: Bağırgan Yayınevi.

Karagözoğlu, C. (2005), Sporda Psikolojik Destek, İstanbul: Morpa Yayınları.

Karasar, N. (2012). Bilimsel Araştırma Yöntemleri (24.Baskı). Ankara: Nobel Akademik Yayıncılık.

Kaya, E. (2013). Çalışan bedensel engelli bireylerin yaşam tatmini örgütsel bağlllık ve iş tatmini düzeylerinin bazı değişkenler açısından incelenmesi. Yüksek Lisans Tezi. Sakarya Üniversitesi, Sakarya.

Köker, S. (1991). Normal ve sorunlu ergenlerin yaşam doyumu düzeyinin karşılaştırılması. Yüksek Lisans Tezi, Ankara Üniversitesi Sosyal Bilimler Enstitüsü, Ankara.

Memnun, S. (2006). Algılanan esenlik ölçeğinin geçerlilik ve güvenirlilik çalışması ve beden eğitimi öğretmenlerinin esenlik algıları. Yüksek Lisans Tezi. Marmara Üniversitesi, İstanbul.

Muraki S, Tsunawake N, Hiramatsu S, \& Yamasaki M. (2000) The effect of frequency and mode of sports activity on the psychological status in tetraplegics and paraplegics. Spinal Cord, 38(5), 309-314.

Rimmer, J. H. (2005). Exercise and physical activity in persons aging with a physical disability. Physical medicine and rehabilitation clinics of North America, 16(1), 41-56. 
Ryff, C. D., \& Singer, B. (2006). Know thyself and become what you are: a eudaimonic approach to psychological well-being. Journal of Happiness Studies, 9,13-39.

Sarıdemir, T. (2015). Öğretmenlerin algılarına göre okul müdürlerinin liderlik stillerinin ve bazı kişisel değişkenlerin öğretmenlerin yaşam doyumu üzerindeki etkisi. Yüksek Lisans Tezi, İstanbul Aydın Üniversitesi, İstanbul.

Saner, H., (2016), Exercise is medicine. J. Preventive Cardiology 5(3), 847-854.

Sevil, T., Şimşek,. K. Y., Katırcı, H., Çelik, V. O., Çeliksoy, M. A., \& Kocaekşi, S. (2012). Boş zaman ve rekreasyon yönetimi. Eskişehir: Anadolu Üniversitesi Yayınları.

Söğüt, M. (2006) Sporun bedensel engellilerin sosyalleşmeleri üzerine etkisi. Yüksek Lisans Tezi, Mersin Üniversitesi, Mersin.

Szabo, A. (2003). The acute effects of humor and exercise on mood and anxiety. Journal of Leisure Research, 35(2), 152-162. 
